\title{
Multivariate approach of inter-relationships among growth, consumption and carcass traits in Nellore cattle ${ }^{1}$
}

\author{
Abordagem multivariada das inter-relações entre características de crescimento, \\ consumo e carcaça em bovinos Nelore
}

\author{
Cláudio Ulhôa Magnabosco ${ }^{2 *}$, Fernando Brito Lopes ${ }^{2}$, Eliane Sayuri Miyagi ${ }^{3}$ Raysildo Barbosa Lôbo ${ }^{4}$ e Roberto \\ Daniel Sainz ${ }^{2}$
}

\begin{abstract}
The objective of the present study was to analyze the phenotypic inter-relationships between growth, feed intake and carcass traits in polled Nellore cattle, as well as to determine which bulls produced the most efficient progeny. The experiment was conducted in the feedlot of the Guaporé Pecuária (Livestock) Company, OB Brand. The following traits were analyzed: initial live weight (ILW); final live weight (FLW); average daily gain (ADG); dry matter intake (DMI); gain:feed (G:F); residual feed intake (RFI); rib-eye area (REA); rump fat thickness (RF); backfat thickness at the 12th-13th rib (BF); weighted fat score (WF); and intramuscular fat percentage (IMF). Both univariate and multivariate analyses were performed to analyze the inter-relationships between the studied traits. No significant phenotypic associations were observed between growth, carcass traits and residual feed intake, while the correlation between RFI and G:F was negative. Therefore, RFI may be used to select more nutritionally efficient animals without compromising growth or adult size. The selection of bulls with progeny showing low residual feed intake is recommended, as selection for low RFI tends to improve feed efficiency without compromising growth and development.
\end{abstract}

Key words: Cluster. Residual feed intake. Multivariate statistic. Weight gain. Zebu.

\begin{abstract}
RESUMO - Objetivou-se analisar os inter-relacionamentos fenotípicos existentes entre características de crescimento, consumo alimentar e de carcaça de bovinos Nelore Mocho, assim como determinar quais touros apresentaram progênies mais eficientes. O experimento foi conduzido no confinamento da Empresa Guaporé Pecuária, Marca OB. As características analisadas foram: peso vivo inicial (PVI); peso vivo final (PVF); ganho em peso diário (GDP); consumo de matéria seca (CMS); eficiência alimentar (EA); consumo alimentar residual (CAR); área de olho de lombo (AOL); espessura de gordura na garupa (EGP8); espessura de gordura na $12^{\mathrm{a}}-13^{\mathrm{a}}$ costela (EG); acabamento (ACAB); e porcentagem de gordura intramuscular (PGIM). Foram realizadas análises uni e multivariadas, a fim de se entenderem os inter-relacionamentos entre as características estudadas. Não foi evidenciada associação fenotípica entre características de crescimento, carcaça e consumo alimentar residual. A correlação entre CAR e EA foi negativa. Assim, ao se utilizar CAR, é possível selecionar animais nutricionalmente mais eficientes sem comprometimento do crescimento e tamanho adulto. Dessa fora, sugere-se a seleção dos touros que apresentaram progênies com baixa estimativa de consumo alimentar residual, pois a seleção de animais de baixo CAR tende a não comprometer o crescimento e desenvolvimento animal, mas sim melhorar a eficiência alimentar dos animais selecionados para essa característica.
\end{abstract}

Palavras-chave: Cluster. Consumo alimentar residual. Estatística multivariada. Ganho em peso. Zebu.

\footnotetext{
*Autor para correspondência

${ }^{1}$ Recebido para publicação em 05/11/2012; aprovado em 05/07/2013

Projeto de pesquisa e desenvolvimento realizado em cooperação técnica com a Marca OB em Pontes e Lacerda - MT

${ }^{2}$ Empresa Brasileira de Pesquisa Agropecuária, Cerrados-GO, Brasil, claudio.magnabosco@embrapa.br, camult@gmail.com, roberto.sainz@ embrapa.br

${ }^{3}$ Programa de Pós-Graduação em Zootecnia, Universidade Federal de Goiás, Goiânia-GO, Brasil, eliane_miyagi@hotmail.com

${ }^{4}$ Associação Nacional de Criadores e Pesquisadores/ANCP, Ribeirão Preto-SP, Brasil, raysildo@gmail.com
} 


\section{INTRODUCTION}

The Brazilian beef industry has grown rapidly in recent years and the growth in beef production is estimated to reach $4.4 \% /$ year by 2015 . This prediction is supported by data showing Brazil as first in world exports of beef, second largest producer of veal and third largest consumer in the world (BRAZIL, 2011).

In Brazil, Zebu breeds (predominantly Nellore) make up about $80 \%$ of the cattle herd, with differences in growth potential and production across regions of the country and also between various management systems (FERRAZ; ELER, 2010). Several researchers have studied growth characteristics such as weights at different ages, growth curves and features related to the standard growth rate of Nellore (GUSMÃO et al., 2009; LOPES et al., 2011; LOPES et al., 2012; SANTOS et al., 2012; SOUZA et al., 2008). However, studies to assess effective feed efficiency, especially relating to residual feed intake and its relationship with growth traits and carcass quality of Nellore cattle in Brazil are still scarce.

Residual feed intake is defined as the difference between the estimated food consumption and the observed food consumption: it is a measure of feed efficiency which presents estimates of genetic and phenotypic correlations close to zero with muscle score at weaning, weaning weight adjusted to 210 days and feed intake and low genetic correlation with feed conversion ratio(BOUQUET et al., 2010). This indicates that different sets of genes influence growth characteristics and residual feed intake. Thus, the adoption of the latter as a tool to select more efficient animals should not compromise the adult size of animals selected for this trait.

Some researchers have reported that residual feed consumption is related to the composition of weight gain in the animals: more efficient animals (negative residual feed intake) tend to have leaner carcasses with less subcutaneous and intramuscular fat deposition (BASARAB , PRICE; AALHUS, 2003; CARSTENS; THEIS; WHITE, 2002; HERD; ARCHER, ARTHUR, 2004; ROBINSON; ODDY., 2004). However, SAINZ, CRUZ AND MONTEIRO (2006), researchers working with Angus-Hereford steers having high and low residual feed intake, found no effect of RFI on hot carcass weight, rib eye area, fat thickness, or marbling fat.

Thus, the aim of this study was to describe the interrelationships between phenotypic traits of growth, feed intake and carcass of polled Nellore cattle and determine which sires had nutritionally more efficient progeny.

\section{MATERIALS AND METHODS}

The experiment was conducted in the Guapore Pecuária (Livestock) Company's feedlot. One hundred fifty polled Nellore bulls, with an average age of 24 months old, offspring of 18 sires mated to 150 females, were used. The animals had received either a protein or an energy supplement on pasture prior to entering the feedlot. The animals were located and fed in individual stalls for 71 days.

The feed provided and leftovers were weighed and dry matter determined daily in order to obtain individual dry matter intakes. The animals were weighed every 28 days, preceded by a solid feed withdrawal period of 16 hours. Average daily gain was estimated as the slope of the regression of live weight on days on feed. At the end of the experiment, carcass traits were obtained using realtime ultrasound, measured by an Ultrasound Guidelines Council-certified technician.

The traits analyzed were: initial live weight (ILW); final live weight (FLW); average daily gain (ADG); dry matter intake (DMI); gain:feed $(\mathrm{G}: \mathrm{F})$; residual feed intake (RFI); ribeye area (REA); rump fat thickness (RF); backfat thickness at the 12th-13th rib (BF); weighted fat score (WF); and intramuscular fat percentage (IMF).

Residual feed intake (RFI) was calculated as the difference between the observed dry matter intake (DMI) and the predicted DMI, using the regression equation as a function of metabolic live weight average $\left(\mathrm{PV}^{0,75}\right)$ and $\mathrm{ADG}$, as proposed by $\mathrm{KOCH}$, SWIGER AND CHAMBERS (1963). The animals were categorized as High RFI (> 0.5 standard deviation above the mean - less efficient), Medium RFI ( \pm 0.5 standard deviation from the mean) and Low RFI ( $<0.5$ standard deviation below the mean - most efficient). Gain:feed was calculated as the ratio of ADG to DMI.

The analyses were divided into two steps: univariate and multivariate. For the univariate analyses, descriptive statistics (mean, standard deviation, minimum and maximum values) were estimated and mean comparison tests (Duncan) between the levels of factors that showed significant differences $(\mathrm{p}<0.05)$ while conducting analysis of variance and Pearson correlation analysis were performed. In this first step, the procedures used were PROC MEANS, GLM and CORR of SAS (2002).

Due to the lack of significance $(p>0.05)$ of fixed factor interactions, these were excluded from the general model, as follows (equation 1):

$Y_{i j k l}=\boldsymbol{\mu}+A_{i}+I_{j}+T_{k}+e_{i j k l}$

where $\boldsymbol{\mu}$ is the overall mean; $\boldsymbol{A}_{i}$ is the feeding effect (ration or protein supplement); $\boldsymbol{I}_{j}$ is the ${ }_{\text {rating index }}$ of residual feed intake effect (high, average and low); $\boldsymbol{T}_{\boldsymbol{k}}$ $\boldsymbol{e}_{i j k l}$ is the residue. 
To further understand the inter-relationships among the studied variables, factor and canonical correlation analyses were conducted. The canonical correlations were partitioned into three subgroups: i) Growth vs. Carcass quality; ii) Intake vs. Carcass quality; and, iii) Growth vs. Intake.

In order to understand and group the sires according to the growth, feed intake and carcass quality trait groups, cluster analyses were implemented using Ward's hierarchical grouping method, using the Mahalanobis generalized distance as a measure of similarity. The procedures used in the multivariate analyses were: PROC FACTOR, CONCOR e CLUSTER. The dendrograms were elaborated by the procedure PROC TREE of SAS (2002).

The efficiency of Ward's hierarchical grouping method was tested by using the correlation coefficient and the number of groups was determined by using the pseudo$\mathrm{F}$ and pseudo- $\mathrm{t}^{2}$ criteria (GONÇALVES et al., 2008).

\section{RESULTS AND DISCUSSION}

The estimated descriptive statistics demonstrated variability for performance, feed intake and carcass traits (Table 1).

The previous feeding regime (Table 2) produced significant differences $(p<0.01)$ in ILW, FLW and G:F. The animals that consumed the energy ration had greater ILW and FLW compared to those that consumed the protein supplement. An RFI effect was found ( $p<0.05)$ only for the features related to feed consumption.
Animals with higher RFI showed higher DMI, while the ones with low RFI consumed less. Animals with High RFI were less efficient, with lower G:F while the ones with Medium and Low RFI showed better feed efficiency and greater G:F. There was no statistical difference $(p>0.05)$ between average and low RFI for G:F.

In contrast to feed conversion ratio, RFI is independent from the patterns of growth and maturity. Therefore, RFI can be a far more accurate and sensitive measure for food utilization, since it is based on energy intake and animals' energy demands. The benefits for RFI based selection were demonstrated by Arthur et al. (1996), who reported that more efficient animals consumed, on average, $13.5 \%$ less food than the estimated, and the less efficient consumed $14 \%$ more than the predicted.

There were significant statistical differences $(\mathrm{p}<0.01)$ between the High, Medium and Low RFI groups, relative to RFI. Group average RFIs were $0.79,-0.01$ and -0.88 for the Hugh, Medium and Low RFI groups, respectively.

Richardson et al. (2001) observed similar results to those reported in this study, in which animals with low RFI had lower rump fat thickness and at the Longissimus dorsi at the beginning of the experiment, but at the end of the test there was no significant difference $(p>0.05)$ between the RFI classes in fat thickness or in rib-eye area (REA) measured by ultrasound. These authors also observed that the subcutaneous fat deposition was similar throughout the experiment, while the most efficient animals had greater REA gains as compared to the less efficient animals.

Table 1 - Descriptive statistics for growth, feed intake and carcass quality traits of polled Nellore cattle

\begin{tabular}{|c|c|c|c|c|c|}
\hline Trait & $\mathrm{N}$ & Mean & Standard Deviation & Minimum & Maximum \\
\hline ILW & 148 & 422 & 44.5 & 336 & 533 \\
\hline FLW & 148 & 513 & 50.2 & 422 & 646 \\
\hline ADG & 148 & 1.28 & 0.29 & 0.36 & 1.97 \\
\hline DMI & 148 & 10.90 & 1.22 & 7.27 & 13.55 \\
\hline $\mathrm{G}: \mathrm{F}$ & 148 & 0.120 & 0.020 & 0.040 & 0.174 \\
\hline RFI & 148 & 0.00 & 0.75 & -1.85 & 1.78 \\
\hline REA & 145 & 76.15 & 7.04 & 63.51 & 104.6 \\
\hline $\mathrm{RF}$ & 144 & 6.68 & 1.55 & 2.69 & 10.78 \\
\hline $\mathrm{BF}$ & 145 & 4.58 & 1.05 & 2.29 & 8.29 \\
\hline WF & 144 & 5.94 & 1.26 & 2.75 & 9.91 \\
\hline IMF & 135 & 4.67 & 1.21 & 2.09 & 8.33 \\
\hline
\end{tabular}

ILW: initial live weight (kg); FLW: final live weight (kg); ADG: average daily gain $\left(\mathrm{kg} \mathrm{day}^{-1}\right)$; DMI: dry matter intake $\left(\mathrm{kg}\right.$ day $\left.{ }^{-1}\right)$; G:F: gain: feed $(\mathrm{kg}$ gain $/ \mathrm{kg} \mathrm{DMI})$; RFI: residual feed intake $\left(\mathrm{kg} \mathrm{day}{ }^{-1}\right)$; REA: rib-eye area $\left(\mathrm{cm}^{2}\right)$; RF: rump fat thickness (mm); BF: backfat thickness at the 12th-13th rib (mm); WF: weighted fat score $(0.35 \mathrm{BF}+0.65 \mathrm{RF})$; and IFP: intramuscular fat percentage $(\%)$ 
Table 2 - Comparison between growth, feed intake and carcass traits of polled Nelore cattle according to previous diet and the RFI group

\begin{tabular}{lcccccc}
\hline \multirow{2}{*}{ Trait } & Feed group & & \multicolumn{3}{c}{ RFI group } & \multirow{2}{*}{ R $^{2}$} \\
\cline { 2 - 5 } & Energy Supplement & Protein Supplement & High & Medium & Low & \\
\hline ILW & $443 \mathrm{a}$ & $381 \mathrm{~b}$ & $423 \mathrm{a}$ & $420 \mathrm{a}$ & $422 \mathrm{a}$ & 0.60 \\
FLW & $532 \mathrm{a}$ & $475 \mathrm{~b}$ & $512 \mathrm{a}$ & $516 \mathrm{a}$ & $510 \mathrm{a}$ & 0.51 \\
ADG & $1.26 \mathrm{a}$ & $1.32 \mathrm{a}$ & $1.24 \mathrm{a}$ & $1.34 \mathrm{a}$ & $1.25 \mathrm{a}$ & 0.24 \\
DMI & $11.12 \mathrm{a}$ & $10.47 \mathrm{a}$ & $11.62 \mathrm{a}$ & $11.03 \mathrm{~b}$ & $9.93 \mathrm{c}$ & 0.56 \\
G:F & $0.11 \mathrm{~b}$ & $0.13 \mathrm{a}$ & $0.11 \mathrm{~b}$ & $0.12 \mathrm{a}$ & $0.12 \mathrm{a}$ & 0.35 \\
RFI & $-0.02 \mathrm{a}$ & $0.03 \mathrm{a}$ & $0.79 \mathrm{a}$ & $-0.01 \mathrm{~b}$ & $-0.88 \mathrm{c}$ & 0.84 \\
REA & $75.51 \mathrm{a}$ & $77.39 \mathrm{a}$ & $75.76 \mathrm{a}$ & $75.63 \mathrm{a}$ & $77.12 \mathrm{a}$ & 0.13 \\
RF & $4.56 \mathrm{a}$ & $4.61 \mathrm{a}$ & $4.65 \mathrm{a}$ & $4.63 \mathrm{a}$ & $4.44 \mathrm{a}$ & 0.16 \\
BF & $6.68 \mathrm{a}$ & $6.67 \mathrm{a}$ & $6.84 \mathrm{a}$ & $6.68 \mathrm{a}$ & $6.49 \mathrm{a}$ & 0.14 \\
WF & $5.94 \mathrm{a}$ & $5.95 \mathrm{a}$ & $6.07 \mathrm{a}$ & $5.97 \mathrm{a}$ & $5.77 \mathrm{a}$ & 0.16 \\
IMF & $4.78 \mathrm{a}$ & $4.44 \mathrm{a}$ & $4.71 \mathrm{a}$ & $4.82 \mathrm{a}$ & $4.48 \mathrm{a}$ & 0.08 \\
\hline
\end{tabular}

abc Lowercase distinct superscripts, on the line, indicates significantly statistical difference ( $p<0.01)$ by Duncan's test; $R^{2}$ : Coefficient of determination; ILW: initial live weight (kg); FLW: final live weight (kg); ADG: average daily gain (kg day $\left.{ }^{-1}\right)$; DMI: dry matter intake $\left(\mathrm{kg} \mathrm{day}^{-1}\right)$; G:F: gain:feed (kg gain/kg DMI); RFI: residual feed intake ( $\left.\mathrm{kg} \mathrm{day}^{-1}\right)$; REA: rib-eye area $\left(\mathrm{cm}^{2}\right)$; RF: rump fat thickness (mm); BF: backfat thickness at the 12 th-13th rib $(\mathrm{mm})$; WF: weighted fat score $(0.35 \mathrm{BF}+0.65 \mathrm{RF})$; and IMF: intramuscular fat percentage $(\%)$

Residual feed intake was positively correlated with DMI and negatively correlated with G:F (Table 3). There were no significant correlations ( $\mathrm{p}>0.05$ ) between RFI and the other traits.

Studies have reported moderate and positive correlations between RFI and DMI, with values of 0.64 for Hereford, 0.60 for Charolais and 0.72 for Angus (HERD; BISHOP, 2000). Genetic selection for low RFI can result in progeny that consume less, but this is only feasible if it does not impair animal performance (HERD; ARCHER; ARTHUR, 2003). Literature estimates are quite variable, but most studies have shown small estimated genetic and phenotypic correlations between RFI and growth traits. This indicates that different sets of genes influence growth traits and RFI. Thus, using RFI as a tool to select more efficient animals should not jeopardize the selected animals' adult size (BONILHA et al., 2009; BOUQUET et al., 2010; HERD; ARCHER; ARTHUR, 2004; RICHARDSON et al., 2001; ROBINSON; ODDY, 2004; SAINZ; CRUZ; MONTEIRO 2006).

According to RICHARDSON et al. (2001), RFI was negatively correlated with carcass traits. ROBINSON e ODDY (2004), however, found a high correlation between RFI and carcass fat measures. Corroborating the results obtained in this experiment, BONILHA et al. (2009) also found no differences in both size and amount of carcass fat of Nellore animals classified according to their RFI.

Considering that the univariate methods are not able to determine and explain the inter-relationship of a set of traits simultaneously, multivariate techniques were used in the second step. This approach enables a better understanding of the causes of variation and is able to detect, in a simple way, the correlations among all the traits analyzed simultaneously.

Thus, factor analyses were important to explain the correlations between the traits through the variations among them. The eigenvectors, derived from factor analysis, indicated that at least five factors should be retained, which were necessary to explain $88 \%$ of the total variance (Table 4).

To better visualize the inter-relationships explained by the sources of variation presented by factorial vectors the eigenvectors Factors 1, 2 and 4 were plotted. Factors 3 and 5 were not used due to the homogeneity of their vector loads, insufficient to satisfactorily describe and discriminate the inter-relationships between the variables under study.

The fourth factor combined growth, carcass, and feed efficiency traits, distinguishing them from RFI, in other words, the variances responsible for explaining RFI variability were not the same that explained the other traits' variability. Therefore, it can be stated that RFI had no significant association with other traits.

The carcass traits (BF, RF and WF) tended to be more closely associated with one another. As for growth traits, the causes of variation that acted upon ILW also acted on FLW, resulting in higher correlation estimates between them. For consumption traits, an antagonism was observed between RFI and G:F (Figure 1). 
Table 3 - Phenotypic correlations among growth, consumption and carcass quality traits of polled Nelore cattle

\begin{tabular}{|c|c|c|c|c|c|c|c|c|c|c|}
\hline \multirow{3}{*}{ ILW } & FLW & $\mathrm{ADG}$ & DMI & $\mathrm{G}: \mathrm{F}$ & RFI & REA & RF & $\mathrm{BF}$ & WF & IMF \\
\hline & 0.912 & 0.066 & 0.542 & -0.263 & 0.023 & -0.026 & -0.023 & -0.038 & -0.030 & 0.116 \\
\hline & $* * *$ & $\overline{\mathrm{ns}}$ & $* * *$ & $* *$ & $\overline{\mathrm{ns}}$ & $\begin{array}{l}\mathrm{ns} \\
\mathrm{n}\end{array}$ & $\overline{\mathrm{ns}}$ & $\overline{\mathrm{ns}}$ & $\overline{\mathrm{ns}}$ & $\overline{\mathrm{ns}}$ \\
\hline \multirow{2}{*}{ FLW } & & 0.469 & 0.730 & 0.127 & 0.024 & -0.012 & 0.010 & -0.030 & 0.000 & 0.166 \\
\hline & & $* * *$ & $* * *$ & ns & ns & ns & ns & ns & ns & ns \\
\hline \multirow{2}{*}{$\mathrm{ADG}$} & & & 0.610 & 0.875 & 0.008 & -0.020 & 0.036 & -0.020 & 0.024 & 0.158 \\
\hline & & & $* * *$ & $* * *$ & ns & ns & ns & ns & ns & ns \\
\hline \multirow{2}{*}{ DMI } & & & & 0.164 & 0.629 & -0.057 & 0.088 & 0.001 & 0.072 & 0.157 \\
\hline & & & & * & $* * *$ & ns & ns & ns & ns & ns \\
\hline \multirow{2}{*}{$\mathrm{G}: \mathrm{F}$} & & & & & -0.339 & 0.009 & -0.013 & -0.042 & -0.022 & 0.103 \\
\hline & & & & & $* * *$ & ns & ns & ns & ns & ns \\
\hline \multirow{2}{*}{ RFI } & & & & & & -0.069 & 0.115 & 0.141 & 0.104 & 0.017 \\
\hline & & & & & & ns & ns & ns & ns & ns \\
\hline \multirow{2}{*}{$\mathrm{FC}$} & & & & & & 0.0462 & 0.0362 & 0.0737 & 0.0503 & -0.103 \\
\hline & & & & & & ns & ns & ns & ns & ns \\
\hline \multirow{2}{*}{ REA } & & & & & & & 0.068 & 0.264 & 0.132 & -0.081 \\
\hline & & & & & & & ns & $* *$ & ns & ns \\
\hline \multirow{2}{*}{ RF } & & & & & & & & 0.586 & 0.971 & 0.075 \\
\hline & & & & & & & & $* * *$ & $* * *$ & ns \\
\hline \multirow{2}{*}{$\mathrm{BF}$} & & & & & & & & & 0.762 & 0.119 \\
\hline & & & & & & & & & $* * *$ & ns \\
\hline \multirow{2}{*}{ WF } & & & & & & & & & & 0.095 \\
\hline & & & & & & & & & & ns \\
\hline
\end{tabular}

Significance: $*(\mathrm{p}<0.05) ; * *(\mathrm{p}<0.01) ; * *(\mathrm{p}<0.001)$; ns: not significant $(\mathrm{p}>0.05)$; ILW: initial live weight $(\mathrm{kg})$; FLW: final live weight $(\mathrm{kg})$; ADG: daily weight gain ( $\left.\mathrm{kg} \mathrm{day}^{-1}\right)$; DMI: dry matter intake ( $\mathrm{kg}$ day $\left.{ }^{-1}\right)$; G:F: gain:feed (kg gain/kg DMI); RFI: residual feed intake $\left(\mathrm{kg}^{2} \mathrm{day}^{-1}\right)$; REA: rib-eye area $\left(\mathrm{cm}^{2}\right)$; RF: rump fat thickness $(\mathrm{mm})$; BF: backfat thickness at the 12th-13th rib (mm); WF: weighted fat score $(0.35 \mathrm{BF}+0.65 \mathrm{RF})$; and IMF: intramuscular fat percentage $(\%)$

Table 4 - Common factors, variance percentage explained by each factor and cumulative variance

\begin{tabular}{lccc}
\hline \multicolumn{1}{c}{ Eigenvectors } & Autovalue & Explained variance $(\%)$ & Cumulative variance $(\%)$ \\
\hline Factor 1 & 3.24 & 0.27 & 0.27 \\
Factor 2 & 2.77 & 0.23 & 0.50 \\
Factor 3 & 2.24 & 0.19 & 0.69 \\
Factor 4 & 1.30 & 0.11 & 0.80 \\
Factor 5 & 1.04 & 0.09 & 0.88 \\
\hline
\end{tabular}

The first factor best represented the FLW, ADG and G:F, in other words, animals with better feed efficiency had higher ADG and FLW. The second factor best explained RFI, BF and WF and can be described as the vector that represented fat deposition

Phenotypically, growth traits (ILW, FLW and ADG) were negatively correlated to REA, BF, WF and RF (Figure 2), corroborating the results shown in Table 3. Canonical correlations estimates, however, were effective in identifying positive correlations between growth traits and intramuscular fat percentage.
By using an univariate approach, no significant correlations were observed ( $p>0.05$ ) between growth, feed intake and carcass groups Figure 3), but the canonical correlation, obtained by using multivariate techniques, demonstrated a positive relationship between: i) RFI, BF and REA, ii) FC, WF and RF 
Figure 1 - Graphical relationship between the eigenvectors 1, 2 and 4 ILW: initial live weight (kg); FLW: final live weight (kg); ADG: average daily gain $\left(\mathrm{kg} \mathrm{day}^{-1}\right)$; DMI: dry matter intake ( $\left.\mathrm{kg} \mathrm{day}^{-1}\right)$; G:F: gain:feed ( $\mathrm{kg}$ gain/kg DMI); RFI: residual feed intake $\left(\mathrm{kg} \mathrm{day}^{-1}\right)$; REA: rib-eye area $\left(\mathrm{cm}^{2}\right)$; RF: rump fat thickness (mm); BF: backfat thickness at the 12th13th rib (mm); WF: weighted fat score $(0.35 \mathrm{BF}+0.65 \mathrm{RF})$; and IMF: intramuscular fat percentage $(\%)$

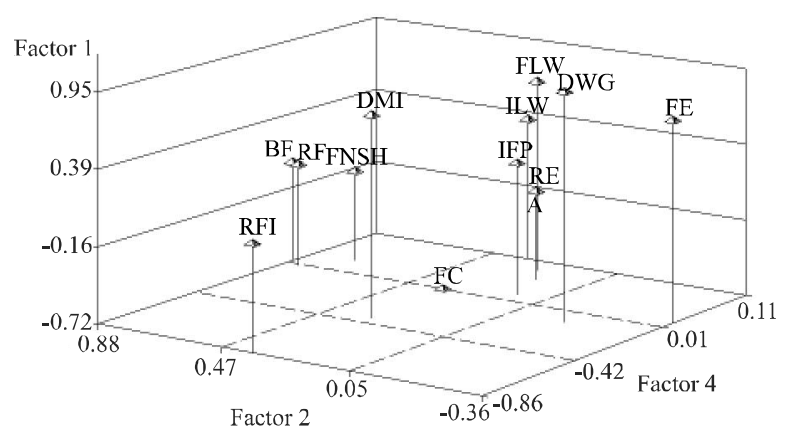

Figure 2 - Canonical correlation between carcass and growth traits ILW: initial live weight $(\mathrm{kg})$; FLW: final live weight (kg); ADG: average daily gain $\left(\mathrm{kg} \mathrm{day}^{-1}\right)$; DMI: dry matter intake ( $\left.\mathrm{kg} \mathrm{day}^{-1}\right)$; G:F: gain:feed (kg gain/kg DMI); RFI: residual feed intake $\left(\mathrm{kg} \mathrm{day}^{-1}\right)$; REA: rib-eye area $\left(\mathrm{cm}^{2}\right)$; RF: rump fat thickness $(\mathrm{mm})$; BF: backfat thickness at the 12th13th rib (mm); WF: finishing $(0.35 \mathrm{BF}+0.65 \mathrm{RF})$; and IMF: intramuscular fat percentage $(\%)$

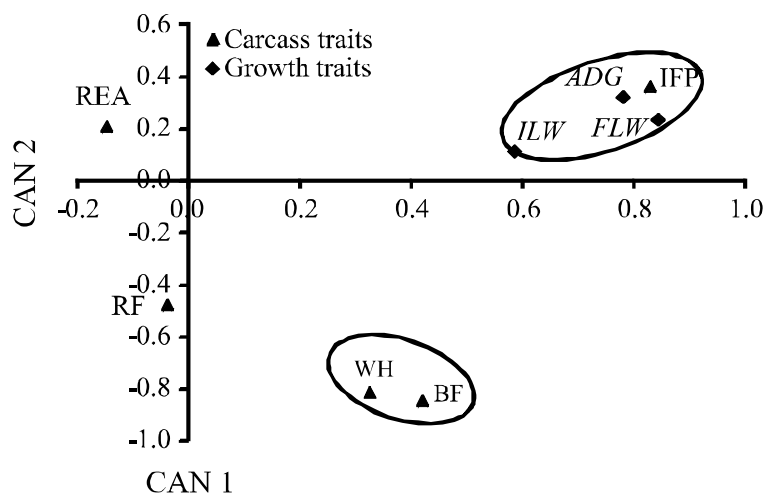

and iii) G:F and IMF. Analyzing canonical vector 2 (CAN 2), it is noted that RFI and G:F are negatively correlated.

The canonical vectors (Figure 4) showed that gain: feed and average daily gain were positively correlated. Likewise, the pairs between final live weight, initial live weight and dry matter intake were also positively correlated.
It was observed that the residual feed intake was near the intersection of the canonical center line (CAN 1 and CAN 2). Indicating that this trait showed no significant canonical relationship with others growth traits (Figure 4).

Figure 3 - Canonical correlation between carcass and consumption traits ILW: initial live weight $(\mathrm{kg})$; FLW: final live weight $(\mathrm{kg})$; ADG: daily weight gain $\left(\mathrm{kg} \mathrm{day}^{-1}\right)$; DMI:

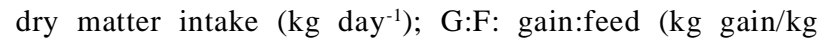
DMI); RFI: residual feed intake $\left(\mathrm{kg} \mathrm{day}^{-1}\right)$; REA: rib-eye area $\left(\mathrm{cm}^{2}\right)$; RF: rump fat thickness $(\mathrm{mm})$; BF: backfat thickness at the 12th-13th rib (mm); WF: weighted fat score $(0.35 \mathrm{BF}+$ $0.65 \mathrm{RF})$; and IMF: intramuscular fat percentage (\%)

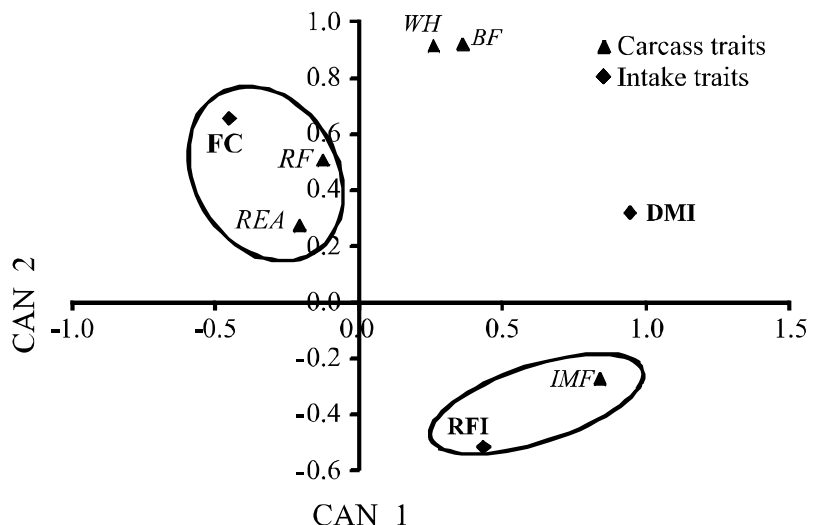

Figure 4 - Canonical correlation between consumption and growth traits ILW: initial live weight $(\mathrm{kg})$; FLW: final live weight (kg); ADG: average daily gain $\left(\mathrm{kg} \mathrm{day}^{-1}\right)$; DMI: dry matter intake (kg day $\left.{ }^{-1}\right)$; G:F: gain:feed (kg gain/kg DMI); RFI: residual feed intake $\left(\mathrm{kg} \mathrm{day}^{-1}\right)$; REA: rib-eye area $\left(\mathrm{cm}^{2}\right)$; RF: rump fat thickness $(\mathrm{mm})$; BF: backfat thickness at the 12th-13th rib (mm); WF: weighted fat score $(0.35 \mathrm{BF}+$ $0.65 \mathrm{RF})$; and IMF: intramuscular fat percentage (\%)

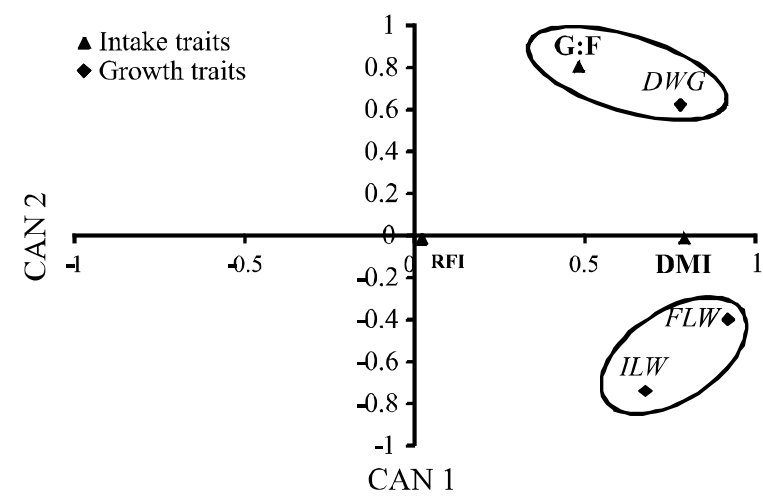


Once the relationships between the phenotypic traits under study were determined, and considering that RFI has moderate heritability (BOUQUET et al., 2010; HOQUE et al., 2009; LANCASTER et al., 2009), clustering (Cluster) analyses were performed in order to identify which of the 18 bulls had nutritionally more efficient progeny, that is, with low estimated RFI.

For growth traits, animals of cluster I showed the greatest average estimate, followed by clusters II and III, in descending order (Table 5). For consumption traits, animals from cluster III had greater DMI than the other clusters. As for gain:feed, bulls from cluster I generated less efficient progeny. The bulls from cluster II had sons with the highest feed efficiency, as well as lower RFI.

Bulls from cluster I also showed the highest average estimate for ribeye area, backfat thickness at the 12th-13th rib, weighted fat score and intramuscular fat percentage, followed by cluster III for REA, RF and WF, while progeny from cluster II had the second highest estimates for BF and IMF.

The clusters formed by each sire were divided into three major groups (I, II and III). Each cluster represented a bull (Table 5 and Figures 5, 6 and 7). For growth traits, group I was formed by bulls B and I; group II by bulls A, $\mathrm{K}, \mathrm{H}, \mathrm{L}, \mathrm{D}, \mathrm{E}, \mathrm{P}, \mathrm{F}, \mathrm{Q}$ and $\mathrm{G}$; and group III was formed by bulls J, O, M, R, C and N (Figure 5).

For food intake traits, group I was formed by bulls F, Q, I and P; group II by bulls A, E, K, L, O, C, G, M, $\mathrm{H}$ and R; and, group III was formed by bulls N, D, J and $\mathrm{B}$ (Figure 6). With regard to carcass traits, group I was formed by bulls A, M, C, H, I, P, F, and K; group II by bulls B, G, O, D, E, J and L; and group III was formed by bulls N, R and Q (Figure 7).

Table 5 - Average estimates for growth, consumption and carcass trait groups as a function of their respective clusters

\begin{tabular}{lrrr}
\hline \multicolumn{1}{c}{ Trait } & \multicolumn{2}{c}{ Cluster } & III \\
\cline { 2 - 4 } & I & II & 428 \\
\hline Initial live weight & 473 & 398 & 520 \\
Final live weight & 570 & 482 & 1.31 \\
Daily weight gain & 1.36 & 1.19 & 11.18 \\
Dry matter intake & 10.49 & 10.51 & 0.12 \\
Gain:Feed & 0.10 & 0.12 & 0.08 \\
Residual feed intake & -0.09 & -0.18 & 76.15 \\
Ribeye area & 78.80 & 74.13 & 6.88 \\
Rump fat thickness & 6.98 & 6.43 & 4.30 \\
Backfat thickness at the 12th-13th rib & 4.92 & 4.45 & 5.98 \\
Weighted fat score & 6.26 & 5.74 & 4.64 \\
Intramuscular fat percentage & 4.72 & 4.64 & \\
\hline
\end{tabular}

Figure 5 - Progeny sire dendrogram grouped according to growth traits

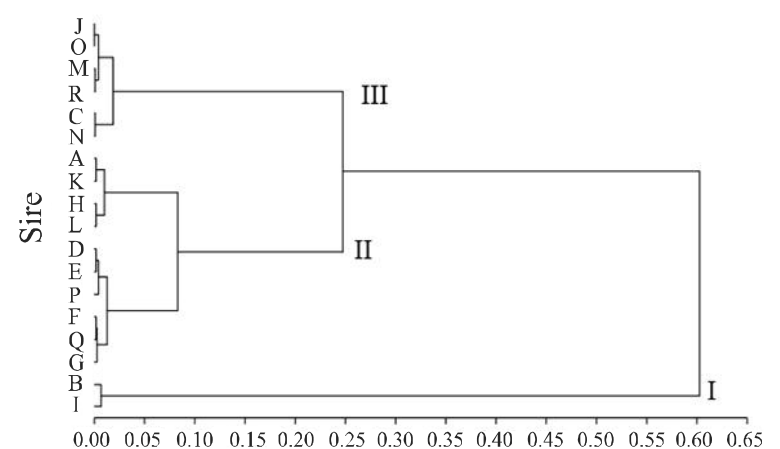

Figure 6 - Progeny sire dendrogram grouped according to consumption traits

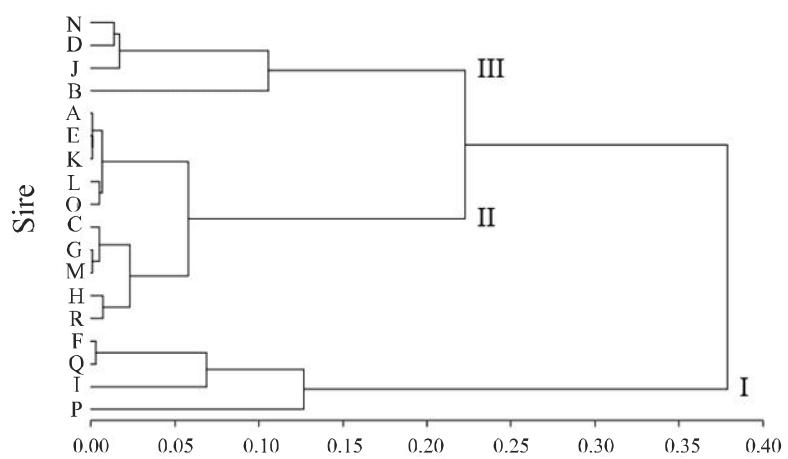


Figura 7 - Progeny sire dendrogram grouped according to carcass quality traits

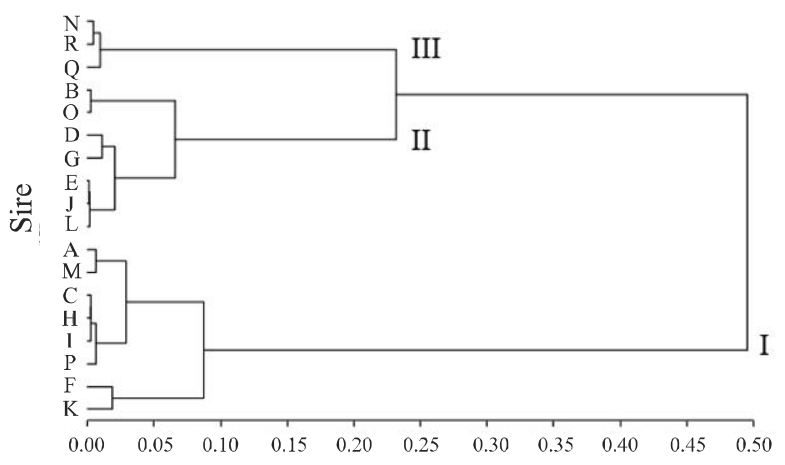

Although sires from cluster II had lower estimates for growth traits, they showed better results for G:F and RFI. Thus, as there were no significant phenotypic correlations (Table 3) ( $p>0.05)$ between growth traits and RFI and also no statistically significant differences ( $p>0.05)$ in growth traits between Low, Medium and High RFI groups (Table 2), sires from cluster II, which showed lower estimates for RFI, are recommended to be parents of future generations.

These results, besides confirming the validity of the tool which has been implemented, demonstrate intrinsic peculiarities of the inter-relationships among the analyzed traits. Thus, it was observed that RFI did not show any phenotypic relationship with ADG, ILW and FLW. Nutritionally, RFI showed a positive association with DMI and a negative association with $\mathrm{G}: \mathrm{F}$, meaning the high RFI animals consumed more food and required a larger amount of dry matter to achieve an average gain at the same weight. Therefore, when using RFI, it is possible to select nutritionally more efficient animals without compromising growth and adult size, as also observed by other authors (LANCASTER et al., 2009; SAINZ; CRUZ; MONTEIRO, 2006).

Residual feed intake is a measure that evaluates whether a given animal consumes more or less feed, in relation to the predicted intake for the animal. This way, variations in RFI must be accounted for by differences in underlying physiological processes (HERD; ARTHUR, 2009). For these authors, RFI is a measure of feed efficiency independent of the productive level, as well as size and growth in beef cattle.

Further studies are warranted to evaluate the phenotypic and genetic interrelationships among growth traits, carcass quality, reproductive and physiological traits. In the face of increasing global demand for food, as well as the reduction in grazing lands, selection of nutritionally more efficient animals, capable of consuming less and producing more, will make the agricultural sector more competitive and sustainable, with reduced environmental impact.

\section{CONCLUSIONS}

1. Residual feed intake was not significantly correlated with the initial and final live weight, average daily gain, ribeye area, rump fat thickness, backfat thickness at the 12th-13th rib, weighted fat score and intramuscular fat percentage;

2. Considering that residual feed intake did not significantly affect growth and carcass traits, the identification of sires with low RFI progeny is recommended, because their use should not jeopardize progeny growth and carcass quality;

3. Animals with lower residual feed intake are nutritionally more efficient, and their use should reduce feed costs and optimize stocking rate.

\section{REFERENCES}

ARTHUR, P. F. et al. Net feed conversion efficiency and its relationship with other traits in beef cattle. Animal Production, v. 21, p. 107-110, 1996.

BASARAB, J. A. et al.. Residual feed intak and body composition in Young growth cattle. Canadian Journal of Animal Science, v. 83, p. 189-204, 2003.

BONILHA, S. F. M. et al. Effects of residual feed intake on carcass characteristics of Nellore bulls. In: ASDA-ASAS JOINT MEeting, 2009, Toronto. Proceedings... Toronto: FASS, 2009.

BOUQUET, A. et al. Genetic parameters for growth, muscularity, feed efficiency and carcass traits of young beef bulls. Livestock Science, v. 129, p. 38-48, 2010.

BRASIL. Ministério da Agricultura, Pecuária e Abastecimento. Projeções do agronegócio: mundial e brasileiro. Disponível em: <http://www.agricultura.gov.br> Acesso em: 20 mar. 2011.

CARSTENS, G. E.; THEIS, C. M.; WHITE, M. B. Relationships between net feed intake and ultrasound measures of carcass composition in growing beef steers. Beef Cattle Research in Texas, v. 2, p. 31-34, 2002.

FERRAZ, J. B. S.; ELER, J. P. Parceria público x privada no desenvolvimento de pesquisa em melhoramento genético animal. Revista Brasileira de Zootecnia, v. 39, p. 216-222, 2010. Suplemento.

GONÇALVES, L. S. A et al. Comparison of multivariate statistical algorithms to cluster tomato heirloom accessions. 
Genetics and Molecular Research, v. 7, n. 4, p. 1289-1297, 2008.

GUSMÃO, F. B. et al. Tendencias genéticas, fenotípicas e ambientais para D160 e D240 em bovinos Nelore no estado da Bahia. Revista Ciência Agronômica, v. 40, n. 02, p. 301305, 2009.

HERD, R. M.; BISHOP, S. C. Genetic variation in residual feed intake and its association with other production traits in British Hereford cattle. Livestock Production Science, v. 63, p. 111-119, 2000.

HERD, R. M.; ARCHER, J. A.; ARTHUR, P. F. Reducing the cost of beef production through genetic improvement in residual feed intake: Opportunity and challenges to application. Journal of Animal Science, v. 81, n. 13, p. 9-17, 2003.

HERD, R. M.; ARCHER, J. A.; ARTHUR, P. F. Steers growth and feed efficiency on pasture are favourably associated with genetic variation in sire net feed intake. Animal Production in Australia, v. 25, p. 93-96, 2004.

HERD, R. M.; ARTHUR, P. F. Physiological basis for residual feed intake. Journal of Animal Science. v. 87, p. E67-E71, 2009.

HOQUE, M. A. et al. Genetic parameters for measures of residual feed intake and growth traits in seven generations of Duroc pigs. Livestock Science. v. 121, n. 1, p. 45-49, 2009.

KOCH, R. M.; SWIGER, L. A.; CHAMBERS, D. et al. Efficiency of feed use in beef cattle. Journal of Animal Science, v. 22, n. 2, p. 486-494, 1963.

LANCASTER, P. A. et al. Phenotypic and genetic relationships of residual feed intake with performance and ultrasound carcass traits in Brangus heifers. Journal of Animal Science, v. 87, n. 12, p. 3887-3896, 2009.
LOPES, F. B. et al. Ajustes de curvas de crescimento em bovinos Nelore da região Norte do Brasil. Revista Brasileira de Saúde e Produção Animal, v. 12, n. 3, p. 607-617, 2011.

LOPES, F. B. et al. Tendência genética para características relacionadas a velocidade de crescimento em bovinos Nelore da região Norte do Brasil. Revista Ciência Agronômica, v. 43, n. 2, p. 362-367 2012.

RICHARDSON, E. C. et al. Body composition and implications for heat production of Angus steers progeny of parents selected for and against residual feed intake. Australian Journal of Experimental Agriculture, v. 41, n. 7, p. 1065-1072, 2001.

ROBINSON, D. L.; ODDY, V. H. Genetics parameters for feed efficiency, fatness, muscle area, and feeding behavior of feedlot finished beef cattle. Livestock Production Science, Amsterdam, v. 90, n. 2/3, p. 255-270, 2004.

SAINZ, R. D.; CRUZ, G. D.; MONTEIRO, R. B. Carcass composition and visceral organs are similar at harvest in low- and high-residual feed intake groups of Angus-Hereford steers. Journal of Animal Science, v. 70, p. 371-381, 2006.

SANTOS, G. C. J. et al. Tendência genética para pesos padronizados aos 205, 365 e 550 dias de idade de bovinos nelore da região Norte do Brasil. Acta Scientiarum. Animal Sciences, v. 34, n. 1, p. 97-101, 2012.

SAS Institute Inc. Statistical Analysis System user's guide. Version 9.0 ed. Cary: SAS Institute, USA, 2002.

SOUZA, J. C. et al. Tendências ambientais e genéticas para características produtivas de bovinos da raça Nelore. Archivos Latinoamericanos de Producción Animal, v. 16, n. 2, p. 85-90, 2008. 